\title{
ESTADO DE NECESSIDADE: A RAZOABILIDADE ENTRE A PRESERVAÇÃO DA VIDA E A LIBERDADE RELIGIOSA
}

\section{Ana Laura Monreal Rosado Cadamuro José Sérgio Saraiva \\ Marcelo Toffano}

ISSUE DOI: $10.21207 / 1983.4225 .597$

\section{RESUMO}

Tratou-se de um estudo com ênfase no direito à vida, com toda proteção jurídica em torno desta, bem como o direito a liberdade religiosa e como dois assuntos tão distintos podem influenciar um ao outro e ainda assim haver tanta divergência em torno de tais temas hoje em dia. A pesquisa em questão objetivou tentar se aprofundar na matéria para entender os argumentos utilizados em ambas as partes quando ocorrer colisão entre tais direitos, como no caso dos adeptos da religião Testemunha de Jeová ao se recusarem a receber transfusão de sangue. Para a realização desta pesquisa foram utilizados livros de diversos ramos do Direito para saber o posicionamento em cada parte deste, leituras da lei seca e por fim estudos nos sites oficiais de seitas religiosas para analisar seus argumentos em torno do assunto. Após toda essa profunda análise em torno das mais diversas opiniões foi possível concluir que em alguns pontos a maioria dos estudiosos do Direito chega a um consenso, como no caso de pessoas que possuem plena 
consciência de seus atos e possuem capacidade civil podem exercer sua liberdade de crença e de escolha, porém em situações emergenciais e que apresentam risco de morte, é dever do médico agir e intervir mesmo com a recusa do paciente, sob pena deste responder pela sua omissão. Para a elaboração deste trabalho foi utilizado o método dedutivo-bibliográfico. Foram também elaborados os seguintes estudos: histórico, dogmático-jurídico e analítico-sintético.

Palavras-chave: Vida. Liberdade religiosa. Transfusão de sangue.

\section{INTRODUÇÃO}

O presente trabalho abordará as diversas proteções jurídicas que garantem ao homem não só o direito à vida, mas também a este viver com dignidade, aprofundando-se na área dos direitos fundamentais, quando estes passam a interferir no direito à vida, como, por exemplo, no caso das Testemunhas de Jeová ao se recusarem a aceitar a transfusão de sangue em decorrência de sua religião.

O estudo em questão tem por objetivo esclarecer ambas as opiniões a respeito do exemplo citado acima.

A pesquisa abordará toda proteção constitucional, civil e penal tanto ao direito à vida bem como a liberdade religiosa e por ambas tratarem-se de garantias constitucionais será abordado as consequências caso uma delas seja violada em decorrência da outra, bem como as punições para os médicos caso não hajam dentro da lei ou deixem de agir.

O trabalho apresentará o método dedutivo-bibliográfico, por partir de conceitos e definições amplas e genéricas e chegar ao caso em particular com uma conclusão.

Serão abordados temas como conceito da vida para diversas áreas de estudos, os aspectos constitucionais do princípio da dignidade da pessoa humana e da liberdade religiosa e de culto, as teorias apontadas pelos adeptos de tal religião bem como seus aspectos civis e as condutas realizadas pelo médico.

O estudo pretende esclarecer os conceitos e pontos de vista de todos os lados além de todas as consequências jurídicas em torno disso, para tentar ao menos diminuir o conflito entre essas duas correntes de pensamentos tão distintas que perduram por anos, inclusive até os dias atuais. 
Para a elaboração deste trabalho foi utilizado o método dedutivobibliográfico. Foram também elaborados os seguintes estudos: histórico, dogmático-jurídico e analítico-sintético.

\section{DA VIDA}

Em um primeiro momento, quando se ouve a palavra vida é possível imaginar diversos significados, conceitos e tipos deste bem tão valioso. Um termo tão pequeno que possui um significado tão imenso é preciso ser estudado e protegido com muita atenção e cautela.

Segundo o dicionário, vida é "o período de tempo que decorre desde o nascimento até a morte dos seres". ${ }^{1}$ Inicialmente tem-se um conceito simples e capaz de suprir quem está à procura de uma resposta sobre um tema tão discutido pelos mais diversos estudiosos entre eles filósofos, juristas, biólogos como tantos outros das mais diversas modalidades de estudos.

Porém ao fazer uma análise mais profunda é possível achar perguntas sem respostas e conflitos em torno de tal tema, que por mais que se discuta a respeito, sempre haverá divergências e novas teorias acerca de velhas discussões, pois muito além do que um simples conceito trata-se de questões que envolvem crenças e convicções muito particulares que geram conflitos entre os membros de uma sociedade que dificilmente serão resolvidos pacificamente.

O real momento de sua origem, bem como o seu final, a disponibilidade do próprio corpo, a disponibilidade da própria vida, são exemplos dessas questões complicadas e que talvez um dia se chegará a uma resposta que nos remeterá em consequência inúmeras outras, nos ajudando em todos os ramos do conhecimento.

Não é de hoje que o homem tenta se adequar o melhor que pode para que se tenha uma vida com dignidade. Garantias constitucionais, convenções e acordos internacionais são bons modelos disso. Passa a ser uma obrigação do Estado proporcionar ao homem uma vida digna e dar-lhe proteção ao seu bem maior (sua vida).

${ }^{1}$ Disponível em: <http://www.dicionariodoaurelio.com/vida> Acesso em: 6 abr. 2015. 
Apesar de tantos fatores que geram dúvidas, não se pode deixar de aprofundar e pesquisar sobre um assunto tão profundo e valioso, para que se garanta cada vez mais a proteção da vida humana em todos os seus aspectos e se resolva tais conflitos que em decorrência deles, podem vir prejudicar a vida de diversas pessoas.

\subsection{CONCEITO}

Tentar idealizar um único conceito para algo tão importante ainda é fonte de divergências e receios. Em cada ramo do conhecimento, tem-se um significado, para cada crença tem-se um critério e para cada indivíduo tem-se uma verdade.

Para as ciências biológicas definir e conceituar o que é vida, também torna-se um árduo trabalho, conforme explica A. Almeida Junior,

A despeito de se haverem ocupado com o assunto muitos dos melhores espíritos da humanidade, não se chegou por ora, a uma definição satisfatória da vida. Pelo que ensina a Lógica, qualquer definição deve convir a todo o definido, e só ao definido. Ora, quando tentamos definir coisas complexas, não podemos evitar de abranger mais do que aquilo que queremos, ou de excluir coisas que desejaríamos abranger. É por isso que, procurando conceituar a vida, experimentamos grande dificuldade em encontrar uma definição que não fique aquém do definido. ${ }^{2}$

Logo neste primeiro conceito, é visível a dificuldade dos estudiosos em encontrar e definir um real significado para a palavra vida. Notase também que na área biológica a vida é considerada algo realmente complexo e de difícil entendimento.

O referido autor cita ainda Aristóteles, para uma definição filosófica, em que conceitua esta, como sendo "o conjunto das operações de

2 ALMEIDA JUNIOR, A. Biologia educacional: noções fundamentais. 20. Ed. São Paulo: Nacional, 1967.p. 32. 
nutrição, crescimento e destruição, cuja causa é um princípio que tem o seu fím em si próprio". 3

Apesar de ter-se chegado a um bom conceito no âmbito filosófico, tal noção de vida torna-se um pouco vaga quando se entra em assuntos mais profundos, como por exemplo, quem é o titular deste conjunto de operações de nutrição, crescimento e destruição ou se tal conjunto trata-se um bem disponível ou não.

No âmbito jurídico, por se discutir as referidas questões acima, não se torna diferente a dificuldade sobre tal conceituação.

Para José Afonso da Silva tentar defini-la, não leva a nada, conforme explica, "não intentaremos dar uma definição disto que se chama vida, porque é aqui que se corre o grave risco de ingressar no campo da metafísica suprarreal, que não nos levará a nada"4. Porém explica que no texto constitucional não será levado em conta apenas a vida no sentido biológico, por tratar-se de algo muito maior,

Vida, no texto constitucional (art. $5^{\circ}$, caput), não será considerada apenas no seu sentido biológico de incessante autoatividade funcional, peculiar à matéria orgânica, mas na sua acepção biográfica mais compreensiva. Sua riqueza significativa é de difícil apreensão porque é algo dinâmico, que se transforma incessantemente sem perder sua própria identidade. ${ }^{5}$

Verificando assim mais uma vez que por mais variados conceitos que já recebeu, a vida é algo muito além do que se pode tentar explicar restando apenas tentar protegê-la e garanti-la.

\subsection{PROTEÇÃO À VIDA}

${ }^{3}$ ALMEIDA JUNIOR, A. Biologia educacional: noções fundamentais. 20. Ed. São Paulo: Nacional, 1967.p. 32.

${ }^{4}$ SILVA, José Afonso da. Curso de direito constitucional positivo. 35 ed. São Paulo: Malheiros editores, 2012. p. 197.

${ }^{5}$ Ibidem. 
A atual Constituição Federal Brasileira protege a vida em vários de seus dispositivos, classificando-a como um direito fundamental, ou seja, prerrogativas essenciais ao homem, que lhes garante uma vida digna, igualitária e com liberdade. Prerrogativas essas, que foram evoluindo ao longo da sociedade, conforme a evolução do homem.

Primeiro, é preciso destacar algumas características dos direitos fundamentais, para que se possa enquadra-las no tema em questão. Tais direitos não são absolutos, ou seja, podem sofrer limitações e restrições, quando tratar-se de interesse público ou enfrentarem outras garantias fundamentais. Assim como podem ser exercidos conjuntamente uns com os outros. Outra característica é a irrenunciabilidade, conforme explica Otávio Piva "o dogma da irrenunciabilidade determina que os direitos e/ou garantias fundamentais não podem ser renunciados pelo seu titular. Admite-se, contudo, que se possa deixar de exercer; mas, repita-se, nunca, propriamente renunciar"6.

Após essa breve análise dos direitos fundamentais é possível ver na prática a proteção constitucional à vida já que logo em seu artigo $1^{\circ}$, inciso III, constitui como um de seus fundamentos básicos a dignidade da pessoa humana ao dispor que, "A República Federativa do Brasil, formada pela união indissolúvel dos Estados e Municípios e do Distrito Federal, constitui-se em Estado Democrático de Direito e tem como fundamentos: III) a dignidade da pessoa humana", .

Em seu art. $5^{\circ}$, caput, garante a todos a inviolabilidade da vida ao afirmar que "todos são iguais perante a lei, sem distinção de qualquer natureza, garantindo-se aos brasileiros, e aos estrangeiros residentes no País, a inviolabilidade do direito à vida, à liberdade, à igualdade, à segurança e a propriedade, nos termos da lei",

Vê-se que mais uma vez, mesmo que indiretamente o Estado garante o direito a uma vida digna, assegurando ao homem viver com liberdade uma vida sem discriminações e sempre com segurança.

No art. 225, a Constituição garante também a vida, ao assegurar um meio ambiente ecologicamente equilibrado,

\footnotetext{
${ }^{6}$ PIVA, Otávio. Comentários ao art. $5^{\circ}$ da constituição federal de 1988 e teoria dos direitos fundamentais. Rio de Janeiro: Método, 2009, p. 21.

${ }^{7}$ Disponível em: < http://www.planalto.gov.br/ccivil_03/constituicao/constituicao.htm> Acesso em: 2 set. 2015.

${ }^{8}$ Ibid.
} 
Todos têm direito ao meio ambiente ecologicamente equilibrado, bem de uso comum do povo e essencial à sadia qualidade de vida, impondo-se ao Poder Público e à coletividade o dever de defendê-lo e preservá-lo para as presentes e futuras gerações. ${ }^{9}$

Em um primeiro momento não é possível pensar que o Estado garante a vida ao assegurar um meio ambiente equilibrado, porém ao analisar mais profundamente observa-se que uma vida digna e com saúde só é possível em um meio ambiente estável que proporciona uma boa qualidade de vida de quem o usufrui.

Já no art. 227, protege a vida da criança e do adolescente, com absoluta prioridade.

É dever da família, da sociedade e do Estado assegurar à criança, ao adolescente e ao jovem, com absoluta prioridade, o direito à vida, à saúde, à alimentação, à educação, ao lazer, à profissionalização, à cultura, à dignidade, ao respeito, à liberdade e à convivência familiar e comunitária, além de coloca-los a salvo de toda forma de negligência, discriminação, exploração, violência, crueldade e opressão. ${ }^{10}$

Constata-se novamente a preocupação do Estado em garantir e proteger a vida humana em todos os seus aspectos, porém na hipótese observada acima, garante a vida da criança, do adolescente e do jovem, que precisam de uma atenção redobrada, tanto do Estado como da sociedade.

E no art. 230, ampara o idoso, garantindo-lhe o bem-estar e o direito a vida, "A família, a sociedade e o Estado têm o dever de amparar as pessoas idosas, assegurando sua participação na comunidade, defendendo sua dignidade e bem-estar e garantindo-lhes o direito a vida" ${ }^{11}$ Por

\footnotetext{
${ }^{9}$ PIVA, Otávio. Comentários ao art. $5^{\circ}$ da constituição federal de 1988 e teoria dos direitos fundamentais. Rio de Janeiro: Método, 2009, p. 21.

${ }^{9}$ Disponível em: < http://www.planalto.gov.br/ccivil_03/constituicao/constituicao.htm> Acesso em: 2 set. 2015.

${ }^{10}$ Disponível em: < http://www.planalto.gov.br/ccivil_03/constituicao/constituicao.htm> Acesso em 02 set. 2015.

${ }^{11}$ Ibid.
} 
fim, para fechar o ciclo da vida o Estado protege a vida do idoso e garantelhe uma velhice com dignidade, devendo a família e a sociedade amparalos sempre.

O Pacto Internacional dos Direitos Civis e Políticos de 1966 dispõe em seu art. $6^{\circ}$ "o direito à vida é inerente à pessoa humana. Ninguém poderá ser arbitrariamente privado de sua vida" ${ }^{\text {12 }}$. Vê-se que mesmo nos Acordos Internacionais é possível observar o cuidado do Estado de garantir e proteger a inviolabilidade da vida humana.

Na Convenção Americana sobre Direitos Humanos (Pacto de San José da Costa Rica), ocorrido em 1969, dispõe em seu art. $4^{\circ}$ que "toda pessoa tem o direito de que se respeite sua vida. Esse direito deve ser protegido pela lei e, em geral, desde o momento da concepção. Ninguém pode ser privado da vida arbitrariamente" ${ }^{13}$.Por tratar-se de convenções internacionais assinadas pelo Brasil, sobre direitos humanos, tais dispositivos possuem caráter constitucional.

Assim sendo, ficam claro as diversas garantias constitucionais à vida humana, bem como afirma Gilmar Ferreira Mendes e Paulo Gustavo Gonet Branco,

Proclamar o direito à vida responde a uma exigência que é prévia ao ordenamento jurídico, inspirando-o e justificando-o. Trata-se de um valor supremo na ordem constitucional, que orienta, informa e dá sentindo último a todos os demais direitos fundamentais. ${ }^{14}$

Observa-se então, a efetiva intenção do Estado em proteger a vida de todo cidadão brasileiro, em todas suas fases e em qualquer momento, garantindo-lhe não só a vida em si, como também uma vida com dignidade e igualdade.

12 Disponível em: <http://www.oas.org/dil/port/1966\%20Pacto\%20Internacional\%20sobre\%20Direitos\%20Civis\%20e\%20Pol\%C3\%ADticos.pdf> Acesso em: 11 abr. 2015.

13 Disponível em: <http://www.pge.sp.gov.br/centrodeestudos/bibliotecavirtual/instrumentos/sanjose.htm> Acesso em 8 abr. 2015.

${ }^{14}$ MENDES, Gilmar Ferreira. BRANCO, Paulo Gustavo Gonet. Curso de direito constitucional.7 ed São Paulo: Saraiva, 2012, p 290. 
O atual Código Civil Brasileiro proclama a vida como um direito da personalidade, como ensina Carlos Roberto Gonçalves,

Certas prerrogativas individuais, inerentes à pessoa humana, aos poucos foram reconhecidas pela doutrina e pelo ordenamento jurídico, bem como protegidas pela jurisprudência. São direitos inalienáveis, que se encontram fora do comércio, e que merecem a proteção legal. [...] São os direitos da personalidade, cuja existência tem sido proclamada pelo direito natural, destacando-se, entre outros, o direito à vida, à liberdade, ao nome, ao próprio corpo, à imagem e à honra. ${ }^{15}$

Uma de suas características é a intransmissibilidade e a irrenunciabilidade, ou seja, não é possível o seu titular dispor de tal direito, tentando transmitir a terceiro ou renunciar deste. Possui também caráter absoluto, decorrente da oponibilidade contra todos.

De acordo com o art. $2^{\circ}$ do Código Civil Brasileiro, a proteção à vida começa a partir do momento da concepção. Apesar de muito discutirse ainda hoje sobre o exato momento de seu início, o atual Código Civil é claro em relação a esse tema, protegendo-a, portanto desde a sua concepção.

Em seu art. 12, garante que seja cessada qualquer ameaça ou lesão, aos direitos de personalidade através das medidas processuais cabíveis, ao afirmar que "pode-se exigir que cesse a ameaça, ou a lesão, a direito da personalidade, e reclamar perdas e danos, sem prejuízo de outras sanções previstas em lei"16. Garante o Código Civil assim a reparação de qualquer dano que possa ameaçar ou lesar a vida.

Já em seu art. 13, proíbe a disposição do próprio corpo, "Salvo por exigência médica, é defeso o ato de disposição do próprio corpo,

${ }^{15}$ GONÇALVES, Carlos Roberto. Direito civil brasileiro v. 1: parte geral. 8. ed. São Paulo: Saraiva, 2010. p. 183.

16 Disponível em: < http://www.planalto.gov.br/ccivil_03/leis/2002/L10406.htm>. Acesso em 9 set. 2015. 
quando importar diminuição permanente da integridade física, ou contrariar os bons costumes" ${ }^{17}$. Como ensina novamente Carlos Roberto Gonçalves

$\mathrm{O}$ direito à integridade física compreende a proteção jurídica à vida, ao próprio corpo vivo ou morto, quer na sua totalidade, quer em relação a tecidos, órgãos e partes suscetíveis de separação e individualização, quer ainda ao direito de alguém submeter-se ou não a exame e tratamento médico.

A vida humana é bem supremo. Preexiste ao direito e deve ser respeitada por todos. É bem jurídico fundamental, uma vez que se constitui na origem e suporte dos demais direitos. ${ }^{18}$

Tal artigo protege a integridade física e a própria vida, pois nem que a pessoa queira ela pode dispor do próprio corpo quando esta importar em diminuição permanente de sua integridade, colocando em risco sua própria vida, estando assim em conformidade o com a Lei ${ }^{\circ} 9.434 / 97$ e o Decreto $n^{\circ} 2.268 / 97$ em que dispõe sobre transplantes de órgãos, pois só é permitido o transplante quando este não acarretar risco de vida para o doador ou não comprometer suas aptidões vitais.

No art. 15 garante também o direito à vida, ao afirmar que "Ninguém pode ser constrangido a submeter-se, com risco de vida, a tratamento médico ou intervenção cirúrgica" ${ }^{19}$. Além de garantir o direito à vida, é visível também a proteção à integridade física, bem como a dignidade da pessoa humana. É preciso respeitar a autonomia do paciente quando este não estiver em situação emergencial ou correr risco de morte.

Por fim vê-se mais uma proteção à vida no art. 948 e 949 dispondo que,

Art. 948 No caso de homicídio, a indenização consiste, sem excluir outras reparações: I- no pagamento

\footnotetext{
17 Disponível em: < http://www.planalto.gov.br/ccivil_03/leis/2002/L10406.htm>. Acesso em 9 set. 2015.

${ }^{18}$ GONÇALVES, Op. cit., p. 193.

${ }^{19}$ Disponível em: < http://www.planalto.gov.br/ccivil_03/leis/2002/L10406.htm> Acesso em 9 set. 2015.
} 
das despesas com o tratamento da vítima, seu funeral e o luto da família; II - na prestação de alimentos às pessoas a quem o morto os devia, levando-se em conta a duração provável da vida da vítima. Art. 949 No caso de lesão ou outra ofensa à saúde, o ofensor indenizará o ofendido das despesas do tratamento e dos lucros cessantes até ao fim da convalescença, além de algum outro prejuízo que o ofendido prove haver sofrido ${ }^{20}$.

No caso do art. 948 é claro a responsabilidade civil daquele que comete ou tenta cometer o homicídio e sua obrigação de reparar tanto material como moralmente a vítima bem como de sua família,incluindo despesas no tratamento da vítima ou os custos do seu funeral, além da prestação de alimentos às pessoas dependentes da vítima. Já o art. 949 igualmente trata da responsabilidade civil com a reparação de danos das despesas do tratamento e dos lucros cessantes ou algum outro prejuízo que o ofendido possa ter sofrido, porém refere-se aos casos de lesão corporal ou ofensa à saúde.

$\mathrm{O}$ atual Código Penal Brasileiro, protege a vida em seus artigos 121 (homicídio), 122 (induzimento, instigação ou auxílio a suicídio), 123 (infanticídio) e do 124 ao 128 (aborto). Esta proteção está dentro do Titulo I, denominado em "Dos crimes contra a pessoa", que garantem também a integridade física, a honra e a liberdade.

Como nos explica Nelson Hungria

A vida é pressuposto da personalidade e é o supremo bem individual. A integridade física é a condição de plenitude de energia e eficiência do indivíduo como pessoa natural. Tutelando esses bens físicos do indivíduo, a lei penal está servindo ao próprio interesse do Estado, pois este tem como elemento principal a população, e à sua prosperidade não é indiferente a saúde ou vitalidade de cada um dos membros do corpo social. E por isso mesmo que correspondem a interesses imediatos ou diretos do Estado, esses bens são inalienáveis, indisponíveis, irrenunciáveis por

${ }^{20}$ Disponível em: < http://www.planalto.gov.br/ccivil_03/leis/2002/L10406.htm> Acesso em 9 set. 2015. 
parte do individuo. Representam o conteúdo de direitos subjetivos que a lei penal considera intangíveis, ainda quando proceda, para o seu ataque, o consentimento do subjectum júris. ${ }^{21}$

O homicídio é a destruição da vida extrauterina de terceiro, podendo ser cometido na forma simples, privilegiada, qualificada, culposa ou com causa de aumento de pena. Será considerado como crime hediondo caso seja cometido quando praticado em atividade típica de grupo de extermínio ou na forma qualificada. Inserindo-se na competência para o Tribunal do Júri, com ação penal pública incondicionada.

O suicídio não é considerado um ilícito penal, porém o seu induzimento, instigação ou auxílio é punido pelo nosso atual ordenamento jurídico, como esclarece Fernando Capez,

Não obstante a lei penal não punir o suicídio, [...] ela pune o comportamento de quem induz, instiga ou auxilia outrem a suicidar-se. É que, sendo a vida um bem público indisponível, o ordenamento jurídico veda qualquer forma de auxílio à eliminação da vida humana, ainda que esteja presente o consentimento do ofendido. $^{22}$

O tipo em questão está previsto nas formas simples e qualificada, com competência também prevista para o Tribunal do Júri e ação penal pública incondicionada.

O infanticídio, também se trata da destruição da vida extrauterina, porém do recém-nascido, devendo ocorrer durante o parto ou logo após, pela mãe em estado puerperal.

Nada mais é do que um homicídio privilegiado, como preceitua Rogério Greco,

${ }^{21}$ HUNGRIA, Nelson. Comentários ao código penal. 5. ed. Rio de Janeiro: Forense, 1979. p. 15-16.

${ }^{22}$ CAPEZ, Fernando. Curso de direito penal: parte especial 14. ed São Paulo: Saraiva, 2014. p.121. v. 2. 
Analisando-se a figura típica do infanticídio, percebese que se trata, na verdade, de uma modalidade especial de homicídio, que é cometido levando-se em consideração determinadas condições particulares do sujeito ativo, que atua influenciado pelo estado puerperal, em meio a certo espaço de tempo, pois que o delito deve ser praticado durante o parto ou logo após. ${ }^{23}$

Pode ser cometido somente na modalidade dolosa. A ação penal é de iniciativa pública incondicionada, com competência para o Tribunal do Júri.

O aborto consiste na interrupção da gravidez, tutelando-se assim a vida intrauterina. Pode ser provocado pela própria gestante, denominadose autoaborto, ou ser provocado por uma terceira pessoa, porém com o cosentimento da gestante, bem como pode ser cometido por uma terceira pessoa, sem o consentimento desta.

Pode o agente responder pela forma majorada, caso a gestante sofra lesão corporal de natureza grave ou perca a vida.

O aborto não será punido quando praticado por médico, "I - se não há outro meio de salvar a vida da gestante. II - se a gravidez resulta de estupro e o aborto é precedido de consentimento da gestante ou, quando incapaz, de seu representante legal" 24 . Sendo assim considerado como uma causa excludente de ilicitude.

Trata-se também de ação penal pública incondicionada, com competência do Tribunal do Júri.

Após essa análise é possível ver que o Estado nem sempre consegue impedir que ocorra a morte do cidadão, porém tenta garantir uma efetiva punição para aquele que cometer tal crime.

\section{$2 \quad$ ASPECTOS CONSTITUCIONAIS}

${ }^{23}$ GRECO, Rogério. Curso de direito penal: parte especial. 6. ed. Niterói: Impetus, 2009. p. 217. v. 2.

24 Disponível em: < http://www.planalto.gov.br/ccivil_03/decretolei/Del2848compilado.htm> Acesso em: 2 set. 2015. 
A atual Constituição Federal Brasileira como se pode observar, garante e protege à vida de todo cidadão brasileiro sem distinção de qualquer natureza. Porém é garantido também a todos o direito a liberdade e dentre os diversos tipos de liberdade, tem-se preservado a liberdade religiosa e de culto.

Aparentemente, a relação entre essas duas garantias tão importantes para o homem é mínima, pois encontram-se em esferas completamente distintas. Porém estas se aproximam quando uma começa a intervir sobre a outra, criando conflitos constitucionais e pessoais, que dependem da crença do homem para que possam ser resolvidos.

\subsection{PRINCÍPIO DA DIGNIDADE DA PESSOA HUMANA}

Para muitos ramos do direito uma das principais fontes utilizadas são os tão falados princípios, podendo ser classificados em princípios gerais, sendo aplicados a todas suas subdivisões e em princípios específicos que se aplicam a apenas determinados ramos.

Princípios segundo José Afonso da Silva, "são ordenações que se irradiam e imantam os sistemas de normas" $" 25$. Assim, as normas devem ser interpretadas conforme os princípios jurídicos, e estes por serem genéricos, podem ser aplicados a diversos ramos do direito.

A dignidade da pessoa humana é um direito inerente a todos os homens, desde a sua concepção até a morte, de serem respeitados e protegidos, sem qualquer discriminação. Pode-se dizer que é o mínimo necessário para que se tenha uma vida saudável, sendo um dever do Estado garantila a todos.

A primeira Constituição a consagrar a dignidade humana, foi à alemã. Em 1948, a Declaração Universal dos Direitos Humanos, garantiu em seu artigo $1^{\circ}$ "que todos os seres humanos nascem livres e iguais em dignidade e direitos. São dotados de razão e consciência e devem agir em relação uns aos outros com espírito de fraternidade." 26 .

${ }^{25}$ SILVA, José Afonso da. Curso de direito constitucional positivo. 35. ed. São Paulo: Malheiros, 2012. p. 92.

26 Disponível em: <http://www.dudh.org.br/wp-content/uploads/2014/12/dudh.pdf> Acesso em: 21 abr. 2015. 
Já primeira Constituição Brasileira a garanti-la foi a de 1988, em seu artigo $1^{\circ}$, inciso III, tendo-a como fundamento de seu Estado Democrático de Direito, dispondo que "A República Federativa do Brasil, formada pela união indissolúvel dos Estados e Municípios e do Distrito Federal, constitui-se em Estado Democrático de Direito e tem como fundamentos: III - a dignidade da pessoa humana" ${ }^{\text {27 }}$.

Apesar da dignidade da pessoa humana estar intimamente ligada ao direito à vida, é preciso resaltar que se tratam de direitos distintos, como explica Ingo Wolfgang Sarlet "é preciso enfatizar que, por mais forte que seja a conexão, dignidade e vida não se confundem. Cuidam-se de direito humanos e fundamentais autônomos, que além disso, podem estar em relação de tensão e mesmo de eventual conflito"28.

Assim, para que se tenha uma vida digna, é preciso que seja respeitado todo e qualquer direito e garantia fundamental, garantindo uma vida sem misérias, bem como igualdade entre todos, liberdade de manifestação de pensamento, de consciência e crença, de expressão das atividades artísticas, intelectuais, cientificas e de comunicação, liberdade de exercício profissional, de locomoção, de reunião, de associação bem como acesso a informação.

\subsection{DA LIBERDADE RELIGIOSA}

A liberdade religiosa atualmente no direito brasileiro está garantida no art. $5^{\circ}$, incisos VI, VII e VIII Constituição Federal, garantindo a inviolabilidade desta.

Dispõe o art. $5^{\circ}$, incisos VI, VII e VIII,

Todos são iguais perante a lei, sem distinção de qualquer natureza, garantindo-se aos brasileiros e aos estrangeiros residentes no País a inviolabilidade do direito à vida, à liberdade, à igualdade, à segurança e à

${ }^{27}$ Disponível em: < http://www.planalto.gov.br/ccivil_03/constituicao/constituicao.htm> Acesso em: 2 set. 2015.

${ }^{28}$ SARLET, Ingo Wolfgang. MARINONI, Luiz Guilherme. MITIDIER, Daniel. Curso de direito constitucional. 3. ed. São Paulo: Revista dos Tribunais, 2014. p. 167. 
propriedade, nos termos seguintes: VI - é inviolável a liberdade de consciência e de crença, sendo assegurado o livre exercício dos cultos religiosos e garantida, na forma da lei, a proteção aos locais de culto e suas liturgias; VII - é assegurada, nos termos da lei, a prestação de assistência religiosa nas entidades civis e militares de internação coletiva; VIII - ninguém será privado de direitos por motivo de crença religiosa ou de convicção filosófica ou política, salvo se as invocar para eximir-se de obrigação legal a todos imposta e recusar-se a cumprir prestação alternativa, fixada em lei. ${ }^{29}$

Ela está inserida na liberdade de consciência, em que nem sempre está relacionado ao aspecto religioso. Conforme Paulo Gustavo Gonet Branco explica ao citar Miguel García Herrera em que

A liberdade de consciência ou de pensamento tem que ver com a faculdade de o indivíduo formular juízos e ideias sobre si mesmo e sobre o meio externo que o circunda. O Estado não pode interferir nessa esfera íntima do indivíduo, não lhe cabendo impor concepções filosóficas aos cidadãos. Deve, por outro lado - eis um aspecto positivo dessa liberdade -, propiciar meios efetivos de formação autônoma da consciência das pessoas. ${ }^{30}$

Na liberdade de crença é garantido ao sujeito escolher sua própria religião, seguir e viver dentro de seus preceitos, bem como muda-la quando quiser. É garantida também a liberdade de ser ateu, porém tal liberdade não enseja o direito de intervir na liberdade de crença de terceiros.

A liberdade religiosa foi garantida também em diversos documentos internacionais. Na Declaração Universal dos Direitos Humanos, de 1948, em seu artigo XVII foi garantido a todo ser humano direito à liberdade de pensamento, consciência e religião, bem como o direito de mudar

${ }^{29}$ Disponível em: < http://www.planalto.gov.br/ccivil_03/constituicao/constituicao.htm> Acesso em: 2 set. 2015

${ }^{30}$ MENDES, Gilmar Ferreira. BRANCO, Paulo Gustavo Gonet. Curso de direito constitucional.7 ed São Paulo: Saraiva, 2012, p 356. 
de religião ou crença e de manifesta-la através do ensino, prática culto e observância.

O Pacto Internacional dos Direitos Civis e Políticos, de 1966, além de proteger a liberdade religiosa, garantiu também que "ninguém poderá ser submetido a medidas coercitivas que possam restringir sua liberdade de ter ou de adotar uma religião ou crença de sua escolha" 31 .Além do fato de poder sofrer limitações quando previstas em lei para proteger a segurança, ordem, saúde, moral pública ou direitos e liberdades das demais pessoas.

O Estado ao garantir a inviolabilidade de tal direito deve permitir que o indivíduo aja de acordo com suas crenças, conforme afirma Paulo Gustavo Gonet Branco,

Se o Estado reconhece a inviolabilidade da liberdade de consciência deve admitir, igualmente, que o indivíduo aja de acordo com as suas convicções. Haverá casos, porém, em que o Estado impõe conduta ao indivíduo que desafia o sistema de vida que as suas convicções construíram. Cogita-se, então, da possibilidade de reconhecer efeitos a uma objeção de consciência.[...] A objeção de consciência consiste, portanto, na recusa em realizar um comportamento prescrito, por força de convicções seriamente arraigadas no indivíduo, de tal sorte, que, se o indivíduo atendesse ao comando normativo sofreria grave tormento moral. ${ }^{32}$

A escusa de consciência está garantida na atual Constituição Brasileira, em seu artigo $5^{\circ}$, inciso VIII, conforme visto anteriormente. Alguns exemplos de tal escusa podem ser a recusa de prestar serviço militar obrigatório, bem como de frequentar aulas e realizações de provas e concursos aos sábados, ou a prática de vivisseção em cursos de nível superior.

O Estado brasileiro atualmente adota o modelo de Estado Laico quanto à religião, ou seja, não possui uma religião oficial, e proíbe qualquer dependência entre o Estado e a Igreja. Estabelecendo em seus princípios

31 Disponível em < http://www.planalto.gov.br/ccivil_03/decreto/19901994/D0592.htm> Acesso em: 2 set. 2015.

${ }^{32}$ MENDES, op. cit., p. 357. 
assim a liberdade de crença bem como qualquer forma de intolerância entre as religiões. Alem disso, por tratar-se de um direito fundamental, poderá sofrer restrições ao se depararem com interesses públicos ou enfrentarem outras garantias constitucionais.

\subsection{DA LIBERDADE DE CULTO}

A liberdade religiosa garantida pela atual Constituição Federal Brasileira protege também a liberdade de culto e a liberdade de organização religiosa em seu artigo $5^{\circ}$, inciso VI, parte final.

Explica Nelson Nery Junior, "o Estado Democrático de Direito não restringe a sua atuação apenas a garantir e a regulamentar a liberdade religiosa, devendo também criar as condições que possibilitem ao cidadão praticar sua fé",33.

A liberdade de culto é para que seja protegida a exteriorização de tais crenças, podendo ser realizados ritos, cerimônias, reuniões bem como manifestações. Porém é preciso cuidado ao classificar todo tipo de ritos como religioso, como salienta Paulo Gustavo Gonet Branco,

Seitas que não tenham natureza religiosa devem ser consideradas alheias à hipótese de imunidade. $\mathrm{O}$ conceito de religião, ademais, liga-se à pré-compreensão que o termo propicia, a referi-lo a um sistema de crenças em um ser divino, em que se professa uma vida além da morte, que possui um texto sagrado, que envolve uma organização e que apresenta rituais de oração e de adoração. Não será um culto religioso uma atividade comercial ou de ensino qualquer, apenas porque se inicia com uma oração. ${ }^{34}$

\footnotetext{
${ }^{33}$ NERY JUNIOR, Nelson. Direito de liberdade e a recusa de tratamento por motivo religioso. In: Revista de Direito Privado. V. 41. p 223. Jan/2010. ${ }^{34}$ MENDES, Gilmar Ferreira. BRANCO, Paulo Gustavo Gonet. Curso de direito constitucional.7 ed São Paulo: Saraiva, 2012, p 361.
} 
Além disso, ressalta Alexandre de Moraes que "a Constituição Federal assegura o livre exercício de culto religioso, enquanto não for contrário à ordem, tranquilidade e sossego públicos, bem como compatível com os bons costumes" $" 35$.

Apesar de possuir tal liberdade de culto, esta poderá ser regulamentada por lei, mas o Estado nunca poderá interferir sobre seus preceitos e verdades. Remetendo-se assim a outra garantia, que se trata da liberdade de organização religiosa, em que é vedado ao Estado interver na economia interna das associações religiosas bem como em sua estrutura e organização.

Outra forma de garantir tal liberdade é a assistência religiosa prevista no artigo $5^{\circ}$, inciso VII da atual Constituição Brasileira, em que esta é assegurada nas entidades civis e militares de internação coletiva. Sendo garantido inclusive que haja local adequado para os cultos religiosos em estabelecimentos prisionais.

Assim mais uma vez, como se trata de garantia fundamental, poderá sofrer restrições e limitações.

\section{A TRANSFUSÃO DE SANGUE E O ENTENDIMENTO DAS TESTEMUNHAS DE JEOVÁ}

Segundo a crença das Testemunhas de Jeová, vida significa uma dádiva de Jeová Deus, devendo ser respeitada tanto a nossa própria vida, como a de terceiros. Em relação ao sangue, é entendido que este representa a vida, não devendo ser ingerido por respeito, bem como para evitar a imoralidade sexual.

Explicam assim em seu site oficial, "mostramos respeito à vida por não arrisca-la desnecessariamente e por não comer sangue [...] portanto, temos de persistir em nos abster de sangue. Aos olhos de Deus, fazer isso é tão importante como evitar a idolatria e a imoralidade sexual. ${ }^{36,}$

\footnotetext{
${ }^{35}$ MORAES, Alexandre de. Direito Constitucional. 24 ed. São Paulo: Atlas, 2009, p 48.

${ }^{36}$ Disponível em <http://www.jw.org/pt/publicacoes/livros/biblia-ensina/respeitar-vida-conceito-de-deus-sobre-aborto-sangue/\#?insight[search_id]=fac59a30dcdb-4896-ada1-b9dd93cb7637\&insight[search_result_index]=4> Acesso 29 abril 2015.
} 
A proibição de abster-se de sangue inclui também a transfusão de sangue, pois a abstenção citada deve ser em todos os aspectos, inclusive ao não permitir que se injete sangue nas veias.

Ao se depararem com uma situação em que seria necessário a transfusão, é recomendado que esta seja recusada e então solicitado um tratamento alternativo. Pois segundo seus princípios, aquele que desobedecer às leis de Deus para viver mais correrá o risco de perder a vida eterna.

Explicam em seus argumentos, que por mais que a transfusão de sangue traga benefícios para a saúde, ela pode trazer malefícios que levam a morte. Um dos exemplos utilizados é o erro que pode ocorrer caso um paciente com sangue tipo A, receba sangue tipo B podendo leva-lo a apresentar uma grave reação hemolítica, destruindo muitas hemácias, e matalo rapidamente.

Outra alegação são as reações adversas que podem ocorrer, tais como febre, calafrio, urticárias, infecções, insuficiência renal aguda, em choque, coagulação intravascular, AIDS e até mesmo a morte. É alegado também o fato de que o sangue coletado em determinado lugar esteja exposto a determinadas doenças que não sejam conhecidas no local do sangue recebido, como explicam,

Um segundo motivo de preocupação é que o sangue coletado em um país em que prolifere determinada doença pode ser usado em local bem distante, onde nem o público nem os médicos estão alertas a seus perigos. Com o aumento das viagens, hoje em dia, inclusive se refugiados e imigrantes, aumenta o risco de um produto de sangue conter uma doença estranha. ${ }^{37}$

Argumentam inclusive que pacientes que recusam transfusão de sangue por motivos religiosos se recuperam mais rápido que outros pacientes, pois recebem um tratamento melhor, por ser procurado evitar a perda de sangue.

Em relação aos tratamentos alternativos citados, são apresentados alguns como por exemplo, utilização de solução salina ou cristaloides

37 Disponível em: <http://www.jw.org/pt/publicacoes/livros/como-pode-o-sangue/As-transfus\%C3\%B5es-de-sangue-qu\%C3\% A3o-seguras-s\%C3\% A3o/\#?insight[search_id]=fac59a30-dcdb-4896-ada1-b9dd93cb7637\&insight[search_result_index]=5> Acesso em 29 abril 2015. 
quando houver uma perda muita rápida e acentuada de sangue e como consequência a baixa da pressão arterial, bem como líquidos dotados de propriedades especiais como a dextrana, para que seja reposto o volume de plasma no sangue. Outra alternativa são as câmaras hiperbáricas

Uma opção para que seja formado mais glóbulos vermelhos, é introduzir nos músculos ou nas veias, concentrados de ferro, ou é possível também fornecer o hormônio eritropoetina, produzido pelos rins.

Salientam também que,

Mesmo no decorrer duma cirurgia, cirurgiões e anestesiologistas peritos e conscienciosos podem ser de ajuda por empregar métodos avançados de conservação de sangue. Nunca é demais enfatizar o uso de técnicas operatórias meticulosas, tais como o bisturi elétrico para minimizar a hemorragia. Às vezes é possível aspirar e filtrar o sangue que flua em um ferimento, repondo-o depois em circulação ${ }^{38}$.

Conforme visto, há profunda recusa dos adeptos desta religião a receberem a injeção de sangue em suas veias, bem como qualquer elemento nele contido, como hemácias, leucócitos, plaquetas, plasma sanguíneo ou imunoglobulinas, mesmo quando estiverem correndo risco de morte.

\section{ASPECTOS CIVIS ACERCA DA TRANSFUSÃO DE SANGUE EM TESTEMUNHA DE JEOVÁ}

Atualmente há uma corrente em que diversos estudiosos do direito entendem que a natureza jurídica entre médico e paciente é uma relação contratual atípica. Em que as partes ao cumprirem todos os requisitos legais ao celebrar um contrato deverão cumpri-lo, sob pena de reparação caso ocorra o descumprimento de algum ato acordado.

${ }^{38}$ Disponível em: < http://www.jw.org/pt/publicacoes/livros/como-pode-o-sangue/Alternativas-de-qualidade-para-a-transfus\%C3\% A3o/\#?insight[search_id]=fac59a30-dcdb-4896-ada1-b9dd93cb7637\&insight[search_result_index] $=9>$ Acesso em 29 abril 2015. 
É necessário ressaltar também a responsabilidade civil do médico, em que somente será responsabilizado caso aja com culpa em sua ação ou omissão.

\subsection{DO CONTRATO}

Contrato é um negócio jurídico bilateral ou plurilateral que gera obrigação para as partes que deste participarem. O contrato atípico está garantido no atual Código Civil em seu artigo 425, desde que sejam observadas as regras gerais do Código Civil Brasileiro.

Dispõe o art. 425 que "é lícito às partes estipular contratos atípicos, observadas as normas gerais fixadas neste Código" "39.

Para que o contrato seja considerado válido, é necessário o preenchimento de certos requisitos. Como explica Carlos Roberto Gonçalves

Os requisitos ou condições de validade dos contratos são de duas espécies: a) de ordem geral, comuns a todos os atos e negócios jurídicos, como a capacidade do agente, o objeto lícito, possível, determinado ou determinável, e a forma prescrita ou não defesa em lei; b) de ordem especial, específico dos contratos: consentimento recíproco ou acordo de vontades. ${ }^{40}$

A falta de capacidade de qualquer uma das partes torna o ato nulo ou anulável. Além disso, é preciso também ter a capacidade específica para se contratar. O consentimento deve ser de ambas as partes em relação à existência e natureza do contrato, o objeto e suas cláusulas, podendo ser tácito ou expresso.

Entende-se por objeto lícito aquele que não infringe a lei. Já a sua possibilidade, pode ser física ou jurídica. E por fim é preciso que seu objeto seja determinado ou ao menos determinável.

${ }^{39}$ Disponível em: < http://www.planalto.gov.br/ccivil_03/leis/2002/L10406.htm> Acesso em 02 set. 2015.

${ }^{40}$ GONÇALVES, Carlos Roberto. Direito civil brasileiro: contratos e atos unilaterais. 10 ed. São Paulo: Saraiva, 2013. p. 34. v. 3. 
O contrato atípico é aquele que não está regulamentado no Código Civil, porém através da necessidade e interesses das partes poderá ser celebrado e tornar-se válido. Pelo fato de não estar devidamente regulamentado, é necessário que seja descrito detalhadamente os direitos e obrigações das partes contratantes, sempre em consonância com as regras gerais descritas acima.

Em relação à natureza jurídica formada entre médico e paciente afirma Márcia Regina Lusa Cadore Weber,

A natureza jurídica da relação instaurada entre médico e paciente, de acordo com Tepedino, pode ser considerada como uma locação de serviços sui generis, figura contratual atípica, na qual agrega-se à prestação remunerada de serviços médicos uma gama de deveres extrapatrimoniais, essenciais à avença, tais como o dever de aconselhar o enfermo. O consenso necessário ao contrato poderá ser expresso ou tácito, manifestado diretamente pelo interessado ou por seus familiares, sem que ausência de instrumento escrito possa ser interpretada como inexistência de negocio jurídico entre as partes. ${ }^{41}$

Atualmente os adeptos de tal religião carregam consigo cartões de identificação em que declaram de forma explícita a sua recusa em receber a transfusão de sangue, para Celso Ribeiro Bastos tal declaração formal constitui-se em ato jurídico válido, conforme explica,

Nota-se que aquela declaração formal feita pelas Testemunhas de Jeová, sob o prisma da legalidade, constitui-se em ato jurídico válido, eis que observa as condicionantes do agente capaz, objeto lícito e forma prescrita ou não defesa em lei[...] Nos cartões de identificação a serem portados por menores de idade, a

${ }^{41}$ WEBER, Márcia Regina Lucia Cadore. Responsabilidade civil do médico. In: Revista de Direito Privado. V. 18. P 144 Abril/2014. 
condição do agente capaz é observada sempre que os pais aponham sua assinatura. ${ }^{42}$

Apesar da recusa poder ser realizada de maneira oral é recomendado que seja de forma escrita para que não ocorra dúvidas quanto a opção de tratamento pelo paciente, porém se isto não for possível é necessário que haja testemunhas diante do médico e do paciente.

\subsection{DA RESPONSABILIDADE CIVIL DO MÉDICO}

Todo aquele que praticar um ato ou deixar de pratica-lo em decorrência de negligência ou imprudência e em razão disso causar dano a terceiros será responsabilizado civilmente por tal conduta ou pela falta dela.

A responsabilidade civil está prevista no atual Código Civil Brasileiro em seu artigo 186, em que dispõe "aquele que, por ação ou omissão voluntária, negligência ou imprudência, violar direito e causar dano a outrem, ainda que exclusivamente moral, comete ato ilícito" ${ }^{43}$.

Assim, caracterizado estará deste modo à responsabilidade civil subjetiva, sendo necessária a comprovação da culpa do agente.

Carlos Roberto Gonçalves lista quatro requisitos essenciais à responsabilidade civil, "ação ou omissão, culpa ou dolo do agente, relação de causalidade e o dano experimentado pela vítima." 44

A responsabilidade do médico não é a de curar o paciente, mas sim a de agir conforme as regras da profissão sempre com clareza e com os devidos cuidados necessários. Tratando-se assim de uma obrigação de meio e não de resultado. Desta forma este só será responsabilizado caso aja com culpa, sendo imprudente, negligente ou imperito.

\footnotetext{
${ }^{42}$ BASTOS, Celso Ribeiro. Direito de recusa de pacientes submetidos a tratamento terapêutico às transfusões de sangue, por razões científicas e convicções religiosas. In: Revista dos Tribunais. V. 787/2001. p 493 Mai/ 2001.

${ }^{43}$ Disponível em: < http://www.planalto.gov.br/ccivil_03/leis/2002/L10406.htm> Acesso em: 2 set. 2015.

${ }^{44}$ GONÇALVES, Carlos Roberto. Direito civil brasileiro: responsabilidade civil 7. ed. São Paulo: Saraiva, 2012 - p. 52. v. 4.
} 
Dispõe o artigo $14, \S 4^{\circ}$ do Código de Defesa do Consumidor "a responsabilidade pessoal dos profissionais liberais será apurada mediante a verificação de culpa"45.

O ônus de provar a culpa do médico pode vir a ser invertida, pois este está sujeito às regras do atual Código de Defesa do Consumidor Brasileiro, e por conta da relação de hipossuficiência entre médico e paciente.

Outro aspecto a ser observado é a obrigação do médico de fornecer de forma clara ao paciente sobre o tratamento utilizado, os riscos que este pode trazer, bem como os remédios que serão ingeridos. Tal dever está previsto no artigo $6^{\circ}$, III do Código de Defesa do Consumidor, que dispõe,

São direitos básicos do consumidor: III - a informação adequada e clara sobre os diferentes produtos e serviços, com especificação correta de quantidade, características, composição, qualidade. tributos incidentes e preços, bem como sobre os riscos que apresentam.

Garantindo ao consumidor dessa forma o principio da transparência, em que obriga o fornecedor a informar ao consumidor as características dos produtos, bem como dos serviços prestados.

O artigo 15 do Código Civil garante que "Ninguém pode ser constrangido a submeter-se, com risco de vida, a tratamento médico ou intervenção cirúrgica" ${ }^{46}$ Ficando evidente a regra em que o médico mesmo em casos graves deve informar ao paciente sobre o seu real estado de saúde e o melhor tratamento indicado, sendo necessária a autorização deste para que seja realizado qualquer procedimento médico em si mesmo. Caso o paciente não possa manifestar sua vontade, a autorização deverá ser dada por escrito, por qualquer parente maior de idade, em linha reta ou colateral até $2^{\circ}$ grau, ou do cônjuge.

Porém caso não haja tempo para que seja providenciada tal autorização, deve o médico agir imediatamente para realizar os procedimentos necessários, como explica Carlos Roberto Gonçalves,

45 Disponível em: < http://www.planalto.gov.br/ccivil_03/Leis/L8078.htm> Acesso em: 2 set. 2015.

${ }^{46}$ Disponível em: < http://www.planalto.gov.br/ccivil_03/leis/2002/L10406.htm> Acesso em: 2 set. 2015. 
Se não houver tempo hábil para ouvir o paciente ou para tomar essas providências, e se tratar de emergência que exige pronta intervenção médica $[. .$.$] terá o$ profissional a obrigação de realizar o tratamento, independentemente de autorização, eximindo-se de qualquer responsabilidade por não tê-la obtido. Responsabilidade haverá somente se a conduta médica mostrar-se inadequada, fruto de imperícia, constituindo-se na causa do dano sofrido pelo paciente ou seu agravamento. ${ }^{47}$

Importante frisar que caso o médico tenha vínculo empregatício com o hospital, este responderá objetivamente, como prestadora de serviços, desde que seja provada a culpa do médico.

A responsabilidade objetiva do médico conforme visto acima, está prevista no art. 14 do Código de Defesa do Consumidor, que dispõe,

O fornecedor de serviços responde, independentemente da existência de culpa, pela reparação de danos causados aos consumidores por defeitos relativos à prestação dos serviços, bem como por informações insuficientes ou inadequadas sobre sua fruição e ris$\cos ^{48}$

A culpa objetiva consiste na obrigação de reparar o dano, independentemente de culpa nos casos específicos em lei ou quando a atividade normalmente desenvolvida pelo autor do dano implicar em risco para os direitos de outrem, conforme art. 927 do Código Civil.

\section{DAS EXCLUDENTES DE ILICITUDE}

\footnotetext{
${ }^{47}$ GONÇALVES, Carlos Roberto. Direito civil brasileiro: responsabilidade civil. 7. ed. São Paulo: Saraiva, 2012. p. 262. v. 4.

48 Disponível em: < http://www.planalto.gov.br/ccivil_03/Leis/L8078.htm> Acesso em: 2 set. 2015.
} 
Entende-se por ilícito ou antijurídico o ato praticado em contrariedade ao ordenamento jurídico, caracterizando assim um fato típico. Porém nem sempre todo fato típico será ilícito, não caracterizando a ocorrência do crime, pois há causas que excluem a ilicitude sendo previstas em lei ou decorrentes da analogia por falta de previsão legal (supralegais), são as chamadas excludentes de ilicitude.

Tais causas excluem apenas a ilicitude e não há que se falar em desaparecimento da tipicidade (correspondência de um caso concreto ao tipo penal previsto). As excludentes em questão são chamadas de normas permissivas, ou tipos permissivos, pois permitem a prática de um fato típico, como explica Fernando Capez, "são tipos penais que não descrevem fatos criminosos, mas hipóteses em que estes podem ser praticados. Por essa razão, denominam-se permissivos. São tipos que permitem a prática de condutas descritas como criminosas" $" 49$.

As causas supralegais aplicam-se através da analogia, costumes ou princípios gerais do direito, como explica Julio Fabbrini Mirabete, citando José Adriano Marrey Neto,

Tem-se sustentado que, além das causas justificativas expressamente consignadas na lei, existem outras, supralegais, não explícitas. A doutrina das justificativas supralegais funda-se na afirmação de que o Direito do Estado, por ser estático, não esgota a totalidade do Direito e a lei não pode esgotar todas as causas de justificativas da conduta humana no plano do ordenamento penal.

[...]As justificativas supralegais são aplicáveis a analogia, os costumes e os princípios gerais de Direito, segundo o critério excelso, de prevalência, em qualquer caso, dos fins sociais a que a lei se destina e das exigências do bem comum. O interprete pode e deve, em certos casos, ir além da só e mecanicista aplicação do texto legal, buscando solução razoável, conforme

${ }^{49}$ CAPEZ, Fernando. Curso de direito penal: parte geral. 16. ed. São Paulo: Saraiva, 2012. p. 211. 
ao Direito, na sua acepção mais ampla e que seja também a mais justa para o caso concreto. ${ }^{50}$.

Já as excludentes de ilicitude legais estão previstas no artigo 23 do atual Código Penal Brasileiro, sendo elas o estado de necessidade, a legítima defesa e o estrito cumprimento de dever legal ou no exercício regular de direito.

\subsection{DA CONDUTA DO MÉDICO}

É necessária extrema cautela ao analisar a conduta a ser tomada pelo médico, pois este poderá responder por constrangimento ilegal caso haja realizado procedimentos sem o consentimento do paciente e sem que este esteja em iminente perigo de morte, de acordo com o artigo 146 do Código Penal Brasileiro, como explica Fernando Capez,

Ausente o consentimento e estando o paciente correndo iminente perigo de vida, caracterizado estará o estado de necessidade em favor de terceiro. Por outro lado, ausente o consentimento e não estando o paciente sofrendo iminente perigo de vida, poderá a intervenção constituir o crime de constrangimento ilegal ${ }^{51}$.

Poderá também responder por omissão de socorro caso deixe realizar os procedimentos necessários, conforme artigo 135 também do Código Penal Brasileiro.

O Conselho Federal de Medicina em sua Resolução CMF $n^{\circ}$ 1.931, de 17 de setembro de 2009 aprovou O Código de Ética Médica, em que em seu artigo 22 dispõe "é vedado ao médico: Deixar de obter consentimento do paciente ou do seu representante legal após esclarecê-lo sobre o procedimento a ser realizado, salvo em caso de risco iminente de morte".

Mais uma vez vê-se o dever do médico de informar o paciente de todo o procedimento que será realizado, porém em casos de iminente risco

\footnotetext{
${ }^{50}$ MIRABETE, Julio Fabbrini. Manual de direito penal: parte geral. 23. ed. São Paulo: Atlas, 2005. p. 170-171.

${ }^{51}$ CAPEZ, op. cit., p. 351.
} 
de morte este poderá agir sem o consentimento exigido. Tal hipótese está protegida legalmente também pelo artigo $146, \S 3^{\circ}$, inciso I do Código Penal em que dispõe,

Constranger alguém, mediante violência ou grave ameaça, ou depois de lhe haver reduzido, por qualquer outro meio, a capacidade de resistência, a não fazer o que a lei permite, ou a fazer o que ela não manda. Pena - detenção, de três meses a um ano, ou multa.

$\S^{\circ}$ Não se compreendem na disposição deste artigo:

I - a intervenção médica ou cirúrgica, sem o consentimento do paciente ou de seu representante legal, se justificada por iminente perigo de vida. ${ }^{52}$ $[\ldots]$

Trata-se de uma causa especial de exclusão de ilicitude, denominada estado de necessidade de terceiro.

\subsection{DO ESTADO DE NECESSIDADE DE TERCEIRO}

No atual ordenamento jurídico, aquele que lesar ou violar o direito de outrem responderá pelo seu ato, porém caso tal lesão seja realizado para salvar um bem próprio ou de terceiro que o próprio agente não tenha dado causa ao perigo, será caracterizado o estado de necessidade.

O estado de necessidade está previsto no art. 24 do Código Penal dispondo que, "considera-se em estado de necessidade quem pratica o fato para salvar de perigo atual, que não provocou por sua vontade, nem podia de outro modo evitar, direito próprio ou alheio, cujo sacrifício, nas circunstâncias, não era razoável exigir-se" ${ }^{, 53}$, caracterizando-se pela exclusão da ilicitude, conforme explica Damásio de Jesus

${ }^{52}$ Disponível em: < http://www.planalto.gov.br/ccivil_03/leis/2002/L10406.htm> Acesso em: 2 set. 2015.

${ }^{53}$ Ibid. 
Estado de necessidade é uma situação de perigo atual de interesses protegidos pelo direito, em que o agente, para salvar um bem próprio ou de terceiro, não tem outro meio senão o de lesar o interesse de outrem.[...]Trata-se de causa de excludente da antijuridicidade. $\mathrm{O}$ art. 23, I, diz que não há crime quando o agente pratica o fato em estado de necessidade. Assim, embora típico o fato, não há crime em face da ausência da ilicitude. ${ }^{54}$.

Conforme visto anteriormente a intervenção cirúrgica sem o consentimento do paciente ou de seu representante legal, quando este estiver em iminente perigo de vida, caracterizará o estado de necessidade de terceiro, pois conforme explica brilhantemente Fernando Capez,

A hipótese do art. 146, $\S 3^{\circ}$, I, poderia, [...] configurar o estado de necessidade em favor de terceiro, pois, em tese, há dois bens jurídicos de terceiro postos em situação de perigo atual, devendo um deles ser sacrificado em prol do bem maior. Tal situação comumente ocorre com enfermos seguidores de religiões que não permitem a intervenção médica ou cirúrgica, como, por exemplo, a proibição de transfusão de sangue, ou, então, nos casos em que a espera pelo consentimento do paciente ou de seu representante legal poderá acarretar-lhe perigo de vida. Assim, há dois interesses em jogo, por um dos quais deverá o médico optar: a preservação do bem jurídico liberdade pessoal [...], ou a preservação do bem jurídico vida. Em face do atual perigo de vida, bem maior, o médico deverá optar pela intervenção médica ou cirúrgica sem o consentimento do ofendido, sacrificando, assim, o bem menor. ${ }^{55}$

Para que se caracterize o estado de necessidade são necessários alguns requisitos como, a situação de perigo atual e iminente, a ameaça ao

\footnotetext{
${ }^{54}$ JESUS, Damásio de. Código penal anotado. 20. ed. São Paulo: Saraiva, 2010. p. 126.

${ }^{55}$ CAPEZ, Fernando. Curso de direito penal: parte especial. 14. ed. São Paulo: Saraiva, 2014. p.352.
} 
direito próprio ou alheio, que a situação não tenha sido causada voluntariamente pelo agente, o conhecimento da situação de fato justificante, a inexistência de dever legal de enfrentar o perigo e a razoabilidade do sacrifício.

Sendo assim, caso sejam reconhecidos todos os requisitos necessários para tal excludente, o médico deverá agir mesmo sem o consentimento e tal intervenção médica ou cirúrgica será típica, porém ilícita.

\subsection{DO ESTRITO CUMPRIMENTO DO DEVER LEGAL E DO EXERCÍCIO REGULAR DE DIREITO}

\subsubsection{DO ESTRITO CUMPRIMENTO DO DEVER LEGAL}

O estrito cumprimento do dever legal é um dever imposto tanto pela lei, como por decretos, regulamentos ou ato administrativos, que se não fossem por estes, tal dever seria considerado um ilícito penal, porém tal excludente não é admitida nos crimes culposos.

Julio Frabbrini Mirabete explica que "quem cumpre regularmente um dever não pode, ao mesmo tempo, praticar ilícito penal, uma vez que a lei não contém contradições" ${ }^{, 56}$.

$\mathrm{O}$ estrito cumprimento do dever legal está garantido no art. 23, inciso III, primeira parte do Código Penal Brasileiro, tratando-se também de um causa de exclusão de ilicitude. "Art. 23 - Não há crime quando o agente pratica o fato: III - em estrito cumprimento de dever legal ou no exercício regular do direito" ${ }^{, 57}$.

Obviamente para que seja reconhecida tal excludente o agente deve agir sempre dentro dos limites permitidos em lei. Além disso, é necessário que o agente seja funcionário ou agente público, incluindo-se inclusive o particular que exerce também função pública.

\footnotetext{
${ }^{56}$ MIRABETE, Julio Fabbrini. Manual de direito penal: parte geral. 23. ed. São Paulo: Atlas, 2005. p. 184-185.

57 Disponível em: < http://www.planalto.gov.br/ccivil_03/decretolei/Del2848compilado.htm> Acesso em: 2 set. 2015.
} 
Os requisitos para que seja reconhecido o estritito cumprimento do dever legal são naturalmente o dever legal, conhecimento da situação justificante e o cumprimento estrito do dever legal.

O dever legal como visto anteriormente é uma obrigação imposta a alguém decorrente da lei, conforme esclarece Luís Augusto Sanzo Brodt,

$\mathrm{O}$ primeiro requisito ao reconhecimento do estrito cumprimento de dever legal há de ser a existência de um dever legal impondo a alguém a prática ou abstenção de conduta descrita em tipo legal de crime. Em todo dever está presente a ideia de vínculo compulsório, subordinação a um comando. O dever legal tem por peculiaridade a circunstância de derivar da lei. ${ }^{58}$.

O conhecimento da situação é um requisito subjetivo, é necessário que o agente saiba que está praticando um ato em decorrência de um dever imposto por lei, pois caso não tenha conhecimento de tal fato, o fato será considerado um ilícito penal.

O cumprimento estrito do dever legal, nada mais é do que agir nos limites impostos pela lei, pois caso o agente ultrapasse tais limites não será caracterizada a excludente. Novamente Luís Augusto Sanzo Brodt explica,

O cumprimento de dever legal só será "estrito" se corresponder à real vontade da ordem jurídica, o que pressupõe a observância dos direitos fundamentais, tanto pelo legislador quanto por quem executa o dever imposto em lei.

A pessoa investida do dever legal de agir tem que verificar, em primeiro lugar, qual o verdadeiro comando que lhe cabe executar, conjugada a lei que o prevê com o conjunto da ordem normativa e, em especial com os preceitos constitucionais consagrados dos direitos fundamentais do homem. Em segundo lugar,

${ }^{58}$ BRODT, Luís Augusto Sanzo. Do estrito cumprimento do dever legal. Porto Alegre: Sergio Antonio Fabris Editor, 2005. p. 125-126. 
deve atuar utilizando-se apenas nos meios compatíveis com o resguardo daquele núcleo de diretos invioláveis. ${ }^{59}$

Assim para que se caracterize a excludente em questão faz-se necessário que sejam comprovado todos os requisitos para que a atitude realizada pelo agente não seja considerada como fato típico.

\subsubsection{DO EXERCÍCIO REGULAR DE DIREITO}

O exercício regular de direito também está previsto no art. 23 inciso III, porém na segunda parte, do Código Penal conforme visto anteriormente na íntegra. Trata-se de uma prerrogativa garantida pelo ordenamento jurídico, que garante ao agente fazer algo que seria considerado crime caso não existisse tal prerrogativa, como explica Fernando Capez,

Causa de exclusão da ilicitude que consiste no exercício de uma prerrogativa conferida pelo ordenamento jurídico, caracterizada como fato típico. [...] qualquer pessoa pode exercitar um direito subjetivo ou uma faculdade previstos em lei (penal ou extrapenal). A Constituição Federal reza que ninguém será obrigado a fazer ou deixar de fazer alguma coisa senão em virtude da lei (CF, art. $\left.5^{\circ} \mathrm{II}\right)$. Disso resulta que se exclui a ilicitude nas hipóteses em que o sujeito está autorizado a esse comportamento. ${ }^{60}$

Nessa hipótese de exclusão de ilicitude abrange-se toda espécie de direito subjetivo, tanto penal como extrapenal, como também os regulamentos ou provisões internas de associações autorizadas legalmente a funcionar.

${ }^{59}$ BRODT, Luís Augusto Sanzo. Do estrito cumprimento do dever legal. Porto Alegre: Sergio Antonio Fabris Editor, 2005. p. 146.

${ }^{60}$ CAPEZ, Fernando. Curso de direito penal: parte geral. 16. ed. São Paulo: Saraiva, 2012. p. 318. 
Assim como no estrito cumprimento do dever legal, também há certos requisitos a serem cumpridos, como agir dentro dos limites impostos pela lei, como explica Damásio de Jesus,

O Código fala em exercício regular de direito, pelo que é necessário que o agente obedeça, rigorosamente , aos requisitos objetivos traçados pelo poder público. Fora daí, há abuso de direito, respondendo o agente pelo fato constitutivo da conduta abusiva. ${ }^{61}$

O outro requisito necessário é o conhecimento da situação justificante, caso o agente não tenha tal conhecimento não há aplicação da exclusão em questão.

O atual Código Penal prevê algumas hipóteses de exercício regular de direito, dentre elas o artigo 146, $\S 3^{\circ}$, em que prevê a prática da intervenção cirúrgica, por tratar-se de atividades autorizadas pelo Estado, dispondo,

Constranger alguém, mediante violência ou grave ameaça, ou depois de lhe haver reduzido, por qualquer outro meio, a capacidade de resistência, a não fazer o que a lei permite ou a fazer o que ela não manda. $\S^{\circ}$ Não se compreendem na disposição deste artigo: I - a intervenção médica ou cirúrgica, sem o consentimento do paciente ou de seu representante legal, se justificada por iminente perigo de vida. ${ }^{62}$

Porém para que se caracterize o exercício regular de direito nas intervenções cirúrgicas é necessário o consentimento do paciente, sendo que este só terá validade caso o bem jurídico seja disponível, que o agente seja capaz de consentir (idade mínima de 18 anos, consentimento expresso e não seja inimputável) e que seja antes ou durante a prática do fato. Caso não haja o consentimento, poderá caracterizar-se o estado de necessidade em favor de terceiro, em situações de emergência em que o agente não

${ }^{61}$ JESUS, Damásio de. Código penal anotado. 20. Ed. São Paulo: Saraiva, 2010. p. 123.

62 Disponível em: < http://www.planalto.gov.br/ccivil_03/decretolei/Del2848compilado.htm> Acesso em: 2 set. 2015. 
puder consentir, o médico poderá fazer a intervenção independente do consentimento.

$$
\text { Assim explica Fernando Capez, }
$$

O consentimento é dispensado em situações de emergência ou nas hipóteses de caso fortuito e força maior, como por exemplo, quando a vítima estiver inconsciente ou sem condições de consentir. Trata-se de causa de exclusão de ilicitude, posto que configurado o exercício regular de direito de exercer profissão. $\mathrm{O}$ mesmo se dá na amputação de membro gangrenado, para salvar a vida do enfermo, ou no aborto necessário (CP, art. 128, I). Em todos esses casos, o consentimento será desnecessário. ${ }^{63}$

Na hipótese do médico agir com imperícia, negligência ou imprudência, não haverá a exclusão do crime e este poderá responder pelo delito culposo.

Importante ressaltar a diferença entre o estrito cumprimento de dever legal e o exercício regular de direito, conforme demonstra Luís Augusto Sanzo Brodt,

No estrito cumprimento de dever legal há uma norma preceptiva, imperativa, que impõe um determinado comportamento a alguém. O sujeito investido do dever de agir não pode deixar de fazê-lo; age compelido, tanto que se não o fizer terá de arcar com a respectiva sansão. Já no exercício regular de direito, o que existe é uma autorização para atuar. Quem tem direito não pode ser compelido a agir. Por conseguinte, nenhuma censura incide sobre o indivíduo que deixa de usufruir um direito. ${ }^{64}$

${ }^{63}$ CAPEZ, Fernando. Curso de direito penal: parte geral. 16. ed. São Paulo: Saraiva, 2012. p. 322 e 323.

${ }^{64}$ BRODT, Luís Augusto Sanzo. Do estrito cumprimento do dever legal. Porto Alegre: Sergio Antonio Fabris Editor, 2005. p. 182. 
Desta forma, caso seja caracterizado o exercício regular de direito, o agente não responderá por crime algum, porém deverá agir sempre dentro dos limites impostos pela lei, caso contrário responderá pelos excessos dolosos ou culposos, tanto nas hipóteses de estado de necessidade de terceiro, estrito cumprimento do dever legal bem como no exercício regular do direito, conforme dispõe o artigo 23, § único do atual Código Penal Brasileiro.

\section{CONCLUSÃO}

A vida é um direito fundamental amplamente protegida e amparada pelo ordenamento jurídico brasileiro. Por tratar-se de uma garantia fundamental protegida inclusive pela Constituição Federal possui algumas características específicas, como o fato de não ser uma garantia absoluta, podendo sofrer restrições e limitações além de ser um direito irrenunciável pelo seu titular.

Em um ramo totalmente distinto, encontra-se a liberdade do cidadão e seu direito de exercê-la. Aprofundando-se ainda mais em uma linha mais específica de liberdade encontra-se, a liberdade de crença e de culto, também protegida pela Constituição Federal, devendo ser respeitada e garantida a qualquer pessoa, porém como qualquer outro direito, pode também vir a sofrer limitações.

O estudo em questão procurou examinar a fundo essas duas garantias tão importantes na vida do homem e tentou chegar a um consenso no momento em que tais direitos se cruzam e criam conflitos entre si.

No primeiro capítulo foram abordados os diversos significados e possíveis conceitos que se encontra para a palavra vida, contudo não foi possível chegar a uma conclusão clara, pois foi verificada a grande dificuldade dos estudiosos em conceitua-la.

Em um segundo momento foram abordadas as diversas garantias constitucionais protegendo a vida, bem como os acordos e tratados internacionais que também a garantem. Garantias estas que protegem a vida do cidadão, bem como sua dignidade, assegurando assim ao homem igualdade, liberdade, segurança e a inviolabilidade ao direito a vida. Tentando garantir a este um meio ambiente equilibrado, incluindo sempre em suas proteções tantos as crianças como os idosos. 
O estudou ressaltou inclusive as proteções que asseguram à vida dentro do Código Civil. Para este a vida é classificada como um direito de personalidade, sendo protegida desde a sua concepção até o momento da morte. Foi analisado inclusive o direito de reparação de qualquer dano que possa ameaçar ou lesar o direito à vida, e a proibição do homem de dispor do próprio corpo quando tal ato importar em diminuição de sua integridade física. Por fim foi observado o direito do cidadão de não ser constrangido a tratamento médico ou intervenção cirúrgica contra a sua vontade, respeitando assim, sua autonomia, salvo em situações emergenciais ou com risco de morte.

Após essa análise, foram abordadas as proteções penais em relação à vida. O Código Penal traz inúmeras consequências para aquele que destruir a vida de outrem ou mesmo auxiliar um terceiro a tirar a própria vida. Tais consequências são aplicadas, além disso, para quem destrói a vida do recém-nascido bem como a destruição da vida intrauterina.

$\mathrm{O}$ estudo em questão analisou que o princípio da dignidade da pessoa humana é um direito inerente a todo cidadão, devendo-lhe ser garantido pelo Estado, o mínimo necessário para que se tenha uma vida saudável, igualitária e com segurança. Além disso, para que se viva com dignidade é necessário que sejam respeitados todos os seus direitos garantidos pelo ordenamento jurídico.

Assim em uma vida com dignidade deve existir consequentemente o direito a uma liberdade religiosa e de culto, sendo também abordadas tais garantias no estudo. A liberdade religiosa está igualmente protegida pela Constituição Federal, inserida esta na liberdade de consciência, garantindo ao indivíduo o direito de escolha da própria religião bem como o direito de ser ateu.

A liberdade de culto da mesma maneira também está garantida pela Constituição Federal. O sujeito ao ter o direito de ter sua própria religião deve ter o direito de poder exercê-la, sendo em forma de ritos, cerimônias, reuniões ou manifestações, salvo quando tais atos contrariarem a ordem ou sossego público.

A pesquisa aprofundou-se no exemplo específico dos adeptos da religião das Testemunhas de Jeová que se recusam a receber transfusão de sangue e em decorrência disso entram em conflito com a irrenunciabilidade da garantia ao direito à vida. 
Segundo o entendimento de tal crença o sangue é uma entidade que representa a vida não devendo ser ingerido de maneira alguma, chegando a tal conclusão através de algumas passagens bíblicas. Ao se depararem com situações em que necessitam receber transfusão de sangue, os seus seguidores são aconselhados a recusarem, sob a pena de perderem a vida eterna. Optam então estes por tratamentos alternativos que nem sempre são totalmente eficazes.

Foi visto posteriormente que a relação médico e paciente é classificada atualmente como uma relação contratual atípica devendo as partes respeitarem o que foi acordado entre elas.

Também foi abordada no estudo a responsabilidade civil do médico, em que obriga este a reparar os danos caso pratique ou deixe de praticar determinado ato em decorrência de negligência ou imperícia. Sendo ressaltado inclusive que o médico deve sempre agir conforme as regras da profissão e com os devidos cuidados, porém não tem o dever de curar o paciente.

Por fim foram analisadas as excludentes de ilicitudes presentes no Código Penal, ou seja, tipos penais que descrevem fatos criminosos, porém em determinadas situações são permitidos a sua prática. Em relação à conduta do médico foi visto que são necessárias algumas cautelas ao examina-la, por exemplo, caso este haja sem o consentimento do paciente e o paciente não esteja em iminente risco de morte ou em situação emergencial, poderá ser configurado o constrangimento ilegal, contudo caso esteja presente o risco de morte ou a situação de emergência será caracterizado o estado de necessidade de terceiro.

Poderão ocorrer inclusive as hipóteses do estrito cumprimento do dever legal, que se trata de um dever imposto por lei, que caso não existisse tal obrigação à conduta seria considerada um ilícito penal ou do exercício regular de direito que igualmente seria considerado crime a conduta do agente, caso este não se enquadre em seus requisitos.

\section{REFERÊNCIAS}

BASTOS, Celso Ribeiro. Direito de recusa de pacientes submetidos a tratamento terapêutico às transfusões de sangue, por razões científicas e convicções religiosas. Revista dos Tribunais. V. 787/2001. Mai 2001 
BRODT, Luís Augusto Sanzo. Do estrito cumprimento do dever legal. Porto Alegre: Sergio Antonio Fabris Editor, 2005

CAPEZ, Fernando. Curso de direito penal - parte especial v. 2. $14^{\mathrm{a}} \mathrm{Ed}$ São Paulo: Saraiva, 2014

. Curso de direito penal - parte geral v. $1.16^{\mathrm{a}} \mathrm{Ed}$ - São Paulo: Saraiva, 2012

Disponível em <http://www.jw.org/pt/publicacoes/livros/biblia-ensina/respeitar-vida-conceito-de-deus-sobre-aborto-sangue/\#?insight[search_id]=fac59a30-dcdb-4896-ada1-b9dd93cb7637\&insight[search_result_index] $=4>$

Disponível em <http://www.planalto.gov.br/ccivil_03/decreto/19901994/D0592.htm>

Disponível em <https://www.cremesp.org.br/?siteAcao=PesquisaLegislacao\&dif $=$ s \& ficha $=1 \&$ id $=8822 \&$ tipo $=$ RESOLU\%C7\% $30 \&$ or gao $=$ Conselho $\% 20$ Federal $\% 20$ de $\% 20$ Medicina\&numero $=1931 \&$ situacao=VIGENTE $\&$ data $=17-09-2009>$

Disponível em: < http://www.jw.org/pt/publicacoes/livros/como-pode-osangue/Alternativas-de-qualidade-para-a-transfus\%C3\% A3o/\#?insight[search_id]=fac59a30-dcdb-4896-ada1-b9dd93cb7637\&insight[search_result_index] $=9>$

Disponível em: < http://www.planalto.gov.br/ccivil_03/constituicao/constituicao.htm>

Disponível em: < http://www.planalto.gov.br/ccivil_03/decretolei/Del2848compilado.htm>

Disponível em: < http://www.planalto.gov.br/ccivil_03/leis/2002/L10406.htm>

Disponível em: < http://www.planalto.gov.br/ccivil_03/Leis/L8078.htm>

Disponível em: <http://www.dicionariodoaurelio.com/vida>

Disponível em: <http://www.dudh.org.br/wp-content/uploads/2014/12/dudh.pdf >

Disponível em: <http://www.jw.org/pt/publicacoes/livros/como-pode-osangue/As-transfus\%C3\%B5es-de-sangue-qu\%C3\%A3o-segurass\%C3\%A3o/\#?insight[search_id]=fac59a30-dcdb-4896-ada1b9dd93cb7637\&insight[search_result_index]=5>

Disponível em: <http://www.oas.org/dil/port/1966\%20Pacto\%20Internacional\%20sobre\%20Direitos\%20Civis\%20e\%20Pol\%C3\%ADticos.pdf $>$

Disponível em: <http://www.pge.sp.gov.br/centrodeestudos/bibliotecavirtual/instrumentos/sanjose.htm> 
GONÇALVES, Carlos Roberto. Direito civil brasileiro v. 1: parte geral. 8 ed - São Paulo: Saraiva, 2010.

. Direito civil brasileiro v. 3: contratos e atos unilaterais. 10 ed São Paulo: Saraiva, 2013.

. Direito civil brasileiro v. 4: responsabilidade civil 7 ed - São

Paulo: Saraiva, 2012

GRECO, Rogério. Curso de direito penal - parte especial v. 2. $6^{\text {a }}$ Ed Niterói: Impetus, 2009.

HUNGRIA, Nelson. Comentários ao código penal. 5a Ed - Rio de Janeiro: Forense, 1979.

JESUS, Damásio de. Código penal anotado. 20ª Ed São Paulo: Saraiva, 2010

MENDES, Gilmar Ferreira. BRANCO, Paulo Gustavo Gonet. Curso de direito constitucional.7 ed São Paulo: Saraiva, 2012

MIRABETE, Julio Fabbrini. Manual de direito penal, parte geral volume 1. $23^{\mathrm{a}}$ Ed revista e atualizada por Renato N Fabbrini - São Paulo: Atlas, 2005

MORAES, Alexandre de. Direito Constitucional. 24 ed. São Paulo: Atlas, 2009

NERY JUNIOR, Nelson. Direito de liberdade e a recusa de tratamento por motivo religioso. Revista de Direito Privado

PIVA, Otávio. Comentários ao art. $5^{\circ}$ da constituição federal de 1988 e teoria dos direitos fundamentais. Rio de Janeiro: Método, 2009

SARLET, Ingo Wolfgang. MARINONI, Luiz Guilherme. MITIDIER, Daniel. Curso de direito constitucional. 3 . ed. São Paulo: Revista dos Tribunais, 2014

SILVA, José Afonso da. Curso de direito constitucional positivo - 35 ed - São Paulo: Malheiros editores, 2012

WEBER, Márcia Regina Lucia Cadore. Responsabilidade civil do médico. Revista de Direito Privado. V. 18. Abril/2014 